\title{
PENGARUH ARUS KAS DAN PENGEMBALIAN MODAL TERHADAP NILAI PERUSAHAAN (Studi Pada PT. Hero Supermarket, Tbk Periode 2004 - 2018)
}

\author{
Rida Ristiyana \\ FEB, Universitas Islam Syekh-Yusuf \\ Email: rristiyana@unis.ac.id
}

\begin{abstract}
The purpose of this study to determine the effect of cash flow and return on capital on firm value at PT. Hero Supermarket, Tbk. The cash flow has a cash ratio proxy, return on capital has a ROE (Return on Equity) proxy and firm value has an EPS proxy (Earning Per Share). The sample of this study was PT. Hero Supermarket, Tbk which submits annual financial reports from the period 2004-2018. The technique of data collection used library study and field survey with the data of observational $(n)=12$. The analytical tool used Multiple Linear Regression. The results of this study, cash ratio has given negative and significant impact on earnings per share, but return on equity has given positive and significant impact on earnings per share.Both, the cash ratio, return on equity showed significantly influence to the earnings per share.
\end{abstract}

Keywords: Earning Per Share, Cash Ratio and Return On Equity 


\section{A. PENDAHULUAN}

Hero Group merupakan kelas ritel dunia yang berasal dari Indonesia dan berubah namanya menjadi Giant untuk segmen Hypermarket. Menurut Kurnia (pemimpin hero group public), "Hero Group dibangun secara lokal, tetapi bekerja dengan standar internasional". Perusahaan didirikan bertujuan untuk memperoleh keuntungan bisnis demi hidup perusahaan yang berkelanjutan dan memantu kegiatan operasional perusahaan dan Hero Group adalah salah satunya. Hero Group senantiasa disebut dengan PT. Hero Supermarket, Tbk.

Menurut Salvatore dalam Hermuningsih (2013: 128) "tujuan utama perusahaan adalah meningkatkan kemakmuran pemilik atau para pemegang saham dengan meningkatkan nilai perusahaan". Pada penelitian ini nilai perusahaan diukur menggunakan proksi laba perlembar saham (earning per share/EPS). EPS merupakan alat analisis keuangan yang menunjukkan kinerja perusahaan apabila dikaitkan dengan saham yang beredar dan harga pasar saham.

Menurut Puspitasari (2010:12) "arus kas operasi dalam suatu perusahaan merupakan salah satu faktor yang sangat penting dalam menciptakan nilai perusahaan. Untuk memaksimalisasi laba dan nilai perusahaan sangatlah tidak mudah diperlukan perencanaan, aksi dan pengendalian untuk mencapai tujuan perusahaan tersebut karenanya perusahaan harus mampu memanfaatkan sumber daya perusahaan melalui perbaikan kinerja manajemen yaitu melalui penggunaan arus kas operasi semaksimal mungkin didalam proses siklus operasi serta melakukan efisiensi terhadap biaya-biaya yang dikeluarkan oleh perusahaan dalam proses produksi". Proksi untuk arus kas operasi pada penelitian ini menggunakan cash ratio. Menurut Guntur (2013:1) "modal adalah salah satu faktor yang mempengaruhi kelangsungan hidup suatu perusahaan. Modal dapat bersumber dari modal sendiri ataupun modal asing. Modal sendiri berupa keuntungan dari perputaran penjualan dan modal asing berupa pinjaman dari para kreditur dan dana investasi para investor".

Menurut Suharli dan Oktorina (2005: 8) "tingkat pengembalian (return) investasi dapat berupa capital gain dan deviden, untuk investasi pada saham, dan pendapatan bunga untuk investasi pada surat hutang. Return tersebut yang menjadi indikator untuk meningkatkan wealth dari para investor termasuk di dalam para pemegang saham. Investor akan sangat senang apabila mendapatkan tingkat pengembalianinvestasinya semakin tinggi dari waktu ke waktu. Oleh karena itu, investor memiliki kepentingan untuk mampu memprediksi berapa besar tingkat 
PENGARUH ARUS KAS DAN PENGEMBALIAN MODAL TERHADAP NILAI PERUSAHAAN (STUDI PADA PT. HERO SUPERMARKET, TBK PERIODE 2004 - 2018)

pengembalian investasi mereka". Untuk pengembalian modal menggunakan proksi ROE (Return on Equity).

Hasil penelitian Wartono (2018); Anwar (2017); Mudhijah (2015) dan Hanafiah (2014) menyatakan bahwa CR berpengaruh terhadap EPS, sedangkan hasil penelitian Nugroho (2017) menyatakan tidak ada pengaruh CR dengan EPS. Hasil penelitian Yunina dkk (2009) ROE berpengaruh terhadap EPS sedangkan hasil penelitian Diaz dan Jufrizen (2014) menyatakan ROE tidak berpengaruh terhadap EPS. Berdasarkan pada latar belakang diatas dan ketidakkonsistenan dari hasil para peneliti maka peneliti ingin menguji kembali pengaruh arus kas, pengembalian modal terhadap nilai perusahaan.

\section{B. TINJAUAN PUSTAKA DAN PENGEMBANGAN HIPOTESIS}

Menurut Kasmir (2015: 138) "cash ratio adalah alat yang digunakan untuk mengukur seberapa besar uang kas yang tersedia untuk membayar utang. Cash ratio merupakan salah satu ukuran dari rasio likuiditas (liquidity ratio) yang merupakan kemampuan perusahaan memenuhi kewajiban jangka pendeknya (current liability) melalui sejumlah kas (dan setara kas, seperti giro atau simpanan lain di bank yang dapat ditarik setiap saat) yang dimiliki perusahaan". "Semakin tinggi cash ratio menunjukkan kemampuan kas perusahaan untuk memenuhi kewajiban jangka pendeknya" (Brigham, 2004 dalam Junaidi, dkk 2014: 2).

Menurut Nugroho (2017) "Return on Equity (ROE) merupakan rasio antara laba setelah pajak atau net income after tax (NIAT) terhadap total modal sendiri (equity) yang berasal dari setoran modal pemilik, laba tak dibagi dan cadangan lain yang dikumpulkan oleh perusahaan".

Menurut Pratama dan Erawati (2014:2) "Earning Per Share merupakan perbandingan antara laba bersih dengan jumlah saham yang beredar. Earning Per Share juga merupakan salah satu indikator rasio perusahaan yang penting. EPS menunjukkan jumlah yang rela dibayarkan oleh investor untuk setiap dolar laba yang dilaporkan". Hipotesis yang bisa diajukan adalah:

$\mathbf{H}_{\mathbf{1}}$ : Arus kas berpengaruh positif dan signifikan terhadap nilai perusahaan pada PT. Hero Supermarket, Tbk

$\mathbf{H}_{2}$ : Pengembalian modal berpengaruh positif signifikan terhadap nilai perusahaan PT. Hero Supermarket, Tbk

$\mathbf{H}_{3}$ : Arus kas dan pengembalian modal berpengaruh secara bersama-sama antara terhadap nilai perusahaan pada PT. Hero Supermarket, Tbk 


\section{METODE PENELITIAN}

Sampel dalam penelitian adalah PT. Hero Supermarket, Tbk yang berlokasi di Graha Hero CBD Bintaro Jaya Sektor 7 Blok B7/A7 Pondok Jaya, Pondok Aren Tangerang Selatan dengan kriteria sampel mengungkapkan laporan keuangan tahunan dari periode 2004-2018, jenis data kuantitatif, sumber data berasal dari laporan keuangan dari periode 2004-2018 yang diperoleh di BEI.Teknik pengumpulan data menggunakan survei lapangan,dan dokumentasi sera studi kepustakaa. Software menggunakan aplikasi SPSS Versi 25.0.

D. HASIL DAN PEMBAHASAN

Tabel 1

Statistik Deskriptif

\begin{tabular}{|l|r|r|r|r|r|}
\hline & $\mathrm{N}$ & $\begin{array}{l}\text { Nilai } \\
\text { Mininum }\end{array}$ & $\begin{array}{c}\text { Nilai } \\
\text { Maksimum }\end{array}$ & Rata-rata & $\begin{array}{c}\text { Standar } \\
\text { Deviasi }\end{array}$ \\
\hline CR & 15 & .032 & .591 & .13907 & .134700 \\
\hline ROE & 15 & -.317 & .238 & .07347 & .135522 \\
\hline EPS & 15 & -298.828 & 918.973 & 248.98167 & 343.959125 \\
\hline $\begin{array}{l}\text { Valid N Data } \\
\text { pengamatan }\end{array}$ & 15 & & & & \\
\hline
\end{tabular}

Sumber: Data diolah (2019)

Berdasarkan pada tabel 1, dapat dijelaskan bahwa:

1) Nilai rata-rata pada Cash Ratio (CR) sebesar 0,139. Hal ini menunjukkan bahwa, rata-rata arus kas PT. Hero Supermarket, Tbk periode 20042018 adalah sebesar 0,139 atau sebesar 13,9 \%. Ini mengindikasikan bahwa cash ratio perusahaan masih tergolong rendah karena dibawah $50 \%$. Nilai terendah cash ratio sebesar 0,032 atau 3,2\% dan nilai tertinggi 0,591 atau 59,1 \% serta standar deviasi sebesar 0,134 . Nilai standar deviasi lebih kecil dibandingkan dengan nilai rata-rata mengindikasikan bahwa jarak data cash ratio pada PT. Hero Supermarket, Tbk periode 2014-2015 tidak bervariatif atau jarak antar data tidak besar. 
PENGARUH ARUS KAS DAN PENGEMBALIAN MODAL TERHADAP NILAI PERUSAHAAN (STUDI PADA PT. HERO SUPERMARKET, TBK PERIODE 2004 - 2018) Rida Ristiyana

2) Nilai rata-rata pada Return On Equity (ROE) sebesar 0,073. Hal ini menunjukkan bahwa, tingkat pengembalian modal PT. Hero Supermarket, Tbk periode 2004-2018 adalah sebesar 0,073 atau sebesar $7,3 \%$. Ini mengindikasikan bahwa tingkat pengembalian modal perusahaan masih tergolong rendah karena dibawah $50 \%$. Nilai terendah ROE sebesar $-0,317$ atau $-31,7 \%$ ini berarti ada laba yang mengalami minus pada periode tertentu dan nilai tertinggi 0,238 atau $23,8 \%$ serta standar deviasi sebesar 0,135. Nilai standar deviasi lebih besar dibandingkan dengan nilai rata-rata mengindikasikan bahwa jarak data ROE pada PT. Hero Supermarket, Tbk periode 2014-2015 bervariatif atau jarak antar data besar.

3) Nilai rata-rata pada Earing Per Share (EPS) sebesar 248,98. Hal ini menunjukkan bahwa, rata-rata nilai perusahaan PT. Hero Supermarket, Tbk periode 2004-2018 adalah sebesar sebesar 248,98 atau sebesar $24,898 \%$. Ini mengindikasikan bahwa nilai perusahaan masih tergolong rendah karena dibawah $50 \%$. Nilai terendah nilai perusahaan sebesar 298,82 atau 29,882\% dan nilai tertinggi 918,97 atau $91,897 \%$ ini berarti sangat besar hamper mencapai $100 \%$, serta standar deviasi sebesar 343,95. Nilai standar deviasinya lebih besar apabila dibandingkan dengan nilai rata-rata mengindikasikan bahwa jarak data nilai perusahaan pada PT. Hero Supermarket, Tbk periode 20142015 bervariatif atau jarak antar data besar.

Tabel 2

Hasil Uji Normalitas Data (Setelah Outlier)

\begin{tabular}{|c|c|c|}
\hline \multicolumn{3}{|c|}{ Tes Kolmogorof Smirnov } \\
\hline & & Residual Tidak Standar \\
\hline \multicolumn{2}{|l|}{ Data pengamatan } & 12 \\
\hline \multirow[t]{2}{*}{ Parameter Normala,b } & Rata-rata & .0000000 \\
\hline & Standar Deviasi & 76.66357383 \\
\hline \multirow{3}{*}{$\begin{array}{l}\text { Perbedaan Nilai } \\
\text { Terektrim }\end{array}$} & Mutlak & .174 \\
\hline & Positif & .174 \\
\hline & Negatif & -.149 \\
\hline \multicolumn{2}{|l|}{ Tes Statistik } & .174 \\
\hline \multicolumn{2}{|l|}{ Signifikansi } & $.200^{c, d}$ \\
\hline \multicolumn{3}{|c|}{ a. Tes distribusinya Normal. } \\
\hline \multicolumn{3}{|c|}{ b. Kalkulasi dari data. } \\
\hline \multicolumn{3}{|l|}{ c. Korelasi Signifikansi. } \\
\hline \multicolumn{3}{|c|}{ d. Ini batas terendah dari signifikansi yang benar. } \\
\hline
\end{tabular}

Sumber: Data diolah (2019) 
Terdapat data outlier pada penelitian ini, tabel 2 menunjukkan uji normalitas setelah outlier. Berdasarkan pada Uji Kolmogorov-Smirno di tabel 2 diperoleh angka probabilitas sebesar 0,200. Dengan taraf signifikansi alpha $5 \%$, diketahui nilai probabilitas $0,200>0,05$, ini berarti $\mathrm{H} 0$ diterima, sehingga, dapat disimpulkan bahwa distribusi data penelitian pada variabel penelitian (arus kas dan pengembalian modal terhadap nilai perusahaan) adalah berdistribusi normal, sehingga model ini layak untuk dilakukan pengujian parametrik (Regresi Linier Berganda).

\section{Tabel 3}

Hasil Uji Multikoliniearitas

Koefisien $^{\text {a }}$

\begin{tabular}{|l|l|r|r|}
\hline \multirow{2}{*}{\multicolumn{2}{|c|}{ Model/ Bentuk }} & \multicolumn{2}{|c|}{ Statistik Koliniaritas } \\
\cline { 3 - 4 } & NilaiToleransi & \multicolumn{1}{c|}{ VIF } \\
\hline \multirow{4}{*}{1} & (Konstan) & & \\
\cline { 2 - 4 } & CR & .995 & 1.005 \\
\cline { 2 - 4 } & ROE & .995 & 1.005 \\
\hline
\end{tabular}

Sumber : Data diolah (2019)

Berdasarkan pada Tabel 3, nilai Toleransi nilainya >0,1 yaitu: untuk variabel Cash Ratio sebesar 0,995; ROE sebesar 0,995. Sedangkan, VIF nilainya < 10, yaitu: variabel Cash Ratio sebesar 1,005; ROE sebesar 1,005; Dari hasil nilai Toleransi $>0,1$ dan hasil nilai VIF $<10$ pada semua variabel, maka data penelitian tidak terjadi gangguan multikoliniearitas dalam regresinya.

Tabel 4

Hasil Uji Autokorelasi

\begin{tabular}{|l|r|}
\hline \multicolumn{2}{|c|}{ Tes Runs } \\
\hline \multicolumn{2}{|c|}{} \\
\hline Nilai Tes ${ }^{a}$ & Residual Tidak Standar \\
\hline Data pengamatan $<$ Nilai Tes & -11.04014 \\
\hline Data pengamatan $>=$ Nilai Tes & 6 \\
\hline Total Data pengamatan & 6 \\
\hline Nomor Runs & 12 \\
\hline$Z$ & 4 \\
\hline Signifikansi & -1.514 \\
\hline a. Nilai Tengah & .130 \\
\hline
\end{tabular}

Sumber : Data diolah (2019) 
Berdasarkan hasil pada Tabel 4 diperoleh hasil Test Value -11,040 dan probabilitas 0,130 signifikan pada 0,05 \% yang berarti hipotesis Nol dapat diterima, sehingga bisa disimpulkan bahwa residual random/tidak terjadi autokorelasi antar nilai residual, sehingga model regresi ini dinyatakan layak untuk dipakai.

\section{Tabel 5}

Hasil Uji Heteroskedastisitas

\begin{tabular}{|c|c|c|c|c|c|}
\hline \multicolumn{6}{|c|}{ Koefisiena } \\
\hline \multirow[b]{2}{*}{ Model } & \multicolumn{2}{|c|}{$\begin{array}{l}\text { Koefisien Tidak } \\
\text { Standar }\end{array}$} & \multirow{2}{*}{\begin{tabular}{|c}
$\begin{array}{c}\text { Koefisien } \\
\text { Standar }\end{array}$ \\
Beta
\end{tabular}} & \multirow[b]{2}{*}{$\begin{array}{c}\mathrm{T} \\
\text { hitung }\end{array}$} & \multirow[b]{2}{*}{ Signifikansi } \\
\hline & B & $\begin{array}{l}\text { Standar } \\
\text { Eror }\end{array}$ & & & \\
\hline 1 (Konstan) & 58.420 & 17.418 & & 3.354 & .008 \\
\hline CR & -58.532 & 70.536 & -.247 & -.830 & .428 \\
\hline ROE & 159.607 & 117.669 & .403 & 1.356 & .208 \\
\hline
\end{tabular}

Sumber: Data diolah (2019)

Berdasarkan pada tabel uji Glejser diatas ditemukan tidak terjadi gangguan heteroskedastisitas pada semua variabel independen, karena nilai signifikansi pada masing-masing variabel independen: Cash Ratio sebesar 0,428; ROE sebesar 0,208. Nilai signifikansi pada semua variabel independen lebih besar bila dibandingkan dengan taraf signifikansi 5\% atau 0,05 yang menunjukkan tidak terjadi gangguan heteroskedastisitas. Sehingga, dapat disimpulkan bahwa semua variabel independen tidak terkena gangguan heteroskedastisitas. 
Tabel 6

Hasil Regresi Linier Berganda

\begin{tabular}{|c|c|c|c|c|c|}
\hline \multirow[b]{2}{*}{ Model } & \multicolumn{2}{|c|}{$\begin{array}{l}\text { Koefisien Tidak } \\
\text { Standar }\end{array}$} & \multirow{2}{*}{$\begin{array}{c}\text { Koefisien } \\
\text { Standar } \\
\text { Beta }\end{array}$} & \multirow[b]{2}{*}{$\begin{array}{c}\mathrm{T} \\
\text { Hitung }\end{array}$} & \multirow[b]{2}{*}{ Signifikansi } \\
\hline & B & $\begin{array}{l}\text { Standar } \\
\text { Eror }\end{array}$ & & & \\
\hline \begin{tabular}{l|l}
1 & (Konstan)
\end{tabular} & 22.916 & 42.783 & & .536 & .605 \\
\hline CR & -468.820 & 173.247 & -.242 & -2.706 & .024 \\
\hline ROE & 3064.976 & 289.014 & .949 & 10.605 & .000 \\
\hline
\end{tabular}

a. Variabel Dependen: EPS

Sumber : Data diolah (2019)

Persamaan regresi linier berganda pada penelitian ini dapat dirumuskan sebagai berikut:

$$
\mathrm{EPS}=22,916-468,820 \mathrm{CR}+3064,976 \mathrm{ROE}+\mathrm{e}
$$

Dimana,

EPS

CR : Cash Ratio (proksi dari arus kas)

ROE : Return On Equity (proksi dari pengembalian modal)

e : error term

Berdasarkan hasil regresi linier berganda pada tabel 6 diatas, dapat dijelaskan sebagai berikut :

1. Konstanta bernilai 22,916 yang artinya apabila Cash Ratio dan ROE nilainya 0, maka EPS adalah sebesar 22,916.

2. Koefisien regresi untuk variabel cash ratio (CR) sebesar $-468,820$; artinya jika variabel independen lainnya tetap dan cash ratio mengalami kenaikan 1 satuan, maka earning per share akan mengalami penurunan sebesar 468,820. Hal ini menunjukkan bahwa semakin bertambah cash ratio maka semakin berkurang EPSnya.

3. Koefisien regresi untuk variabel ROE sebesar 3064,976; artinya jika variabel independen lainnya tetap dan ROE mengalami kenaikan 1 satuan, maka earning per share akan mengalami kenaikan sebesar 3064,976. Hal ini menunjukkan bahwa semakin bertambah ROE maka semakin bertambah pula EPSnya. 
PENGARUH ARUS KAS DAN PENGEMBALIAN MODAL TERHADAP NILAI PERUSAHAAN (STUDI PADA PT. HERO SUPERMARKET, TBK PERIODE 2004 - 2018)

Rida Ristiyana

\section{Tabel 7}

Hasil Uji Koefisien Determinasi

\begin{tabular}{|l|r|r|r|r|}
\hline \multicolumn{5}{|c|}{ Ringkasan Model } \\
\hline Model & $\mathrm{R}$ & R Square & $\begin{array}{c}\text { Adj. R } \\
\text { Square }\end{array}$ & $\begin{array}{c}\text { Standar } \\
\text { Estimasi Eror }\end{array}$ \\
\hline 1 & $.963 \mathrm{a}$ & .928 & .912 & 84.754770 \\
\hline \multicolumn{4}{|l|}{ a. Indikator: (Konstan), ROE, CR } \\
\hline \multicolumn{4}{|l}{ b. Variabel Dependen: EPS } \\
\hline
\end{tabular}

Sumber : Data diolah (2019)

Nilai koefisien determinasi (Adj. $R^{2}$ ) sebesar 0,912. Hal ini menunjukkan bahwa kemampuan variabel Cash Ratio dan ROE adalah sebesar 91,2 \% dalam memprediksi Earning Per Share. Sedangkan, sebagian yaitu sebesar 8,8 \% (100 \% - 91,2 \%) =8,8\% ) dijelaskan oleh faktor- faktor lain selain variabel yang diteliti (dijelaskan oleh faktor-faktor lain yang berpengaruh terhadap variabel EPS yang tidak diteliti).

Tabel 8

Hasil Uji F

\begin{tabular}{|c|c|c|c|c|c|c|}
\hline \multicolumn{7}{|c|}{ ANOVA $^{a}$} \\
\hline \multicolumn{2}{|c|}{ Model } & $\begin{array}{l}\text { Jumlah } \\
\text { Squares }\end{array}$ & $\mathrm{df}$ & $\begin{array}{c}\text { Rata-rata } \\
\text { Square }\end{array}$ & $\begin{array}{c}\mathrm{F} \\
\text { Hitung }\end{array}$ & Signifikansi. \\
\hline & Regresi & 835909.781 & 2 & 417954.891 & 58.184 & $.000^{\mathrm{b}}$ \\
\hline & Residu & 64650.339 & 9 & 7183.371 & & \\
\hline & Total & 900560.120 & 11 & & & \\
\hline \multicolumn{7}{|c|}{\begin{tabular}{|l|} 
a. Variabel Dependen: EPS \\
\end{tabular}} \\
\hline \multicolumn{7}{|c|}{ b. Indikator: (Konstan), ROE, CR } \\
\hline
\end{tabular}

Sumber : Data diolah (2019)

Pada tabel 8, diketahui angka $\mathrm{F}$ hitung sebesar 58,184 dengan nilai probabilitas 0,000. Dengan $\mathrm{k}=2, \mathrm{n}=12$, maka df1 $=2, \mathrm{df} 2=\mathrm{n}-\mathrm{k}-1=12$ $2-1=9$, diperoleh nilai $F$ tabel sebesar 4,26. Jadi, diperoleh F hitung 58,184 $>\mathrm{F}$ tabel 4,26. Selain itu, nilai probabilitas sebesar 0,000 lebih kecil dari taraf signifikansi $5 \%$, sehingga dapat disimpulkan bahwa secara bersama-sama (model penelitian) ada pengaruh yang signifikan antara variabel independen/bebas, yaitu: Cash Ratio dan ROE terhadap EPS atau dapat dijelaskan bahwa model penelitian dikatakan fit atau layak. 


\section{Uji Signifikansi Individual (Uji Statistik $t$ )}

Uji hipotesis $t$ antara satu variabel independen terhadap variabel dependen. Pada pengujian ini dilakukan derajat kebebasan sebesar 5\% dengan jumlah data yang diobservasi sebanyak 12 (setelah outlier) data dan hasil uji $t$ dapat dilihat pada tabel 6 .

Berdasarkan hasil uji t pada tabel 6 dapat dijelaskan sebagai berikut:

1) Uji Pengaruh individual (uji t) antara variabel Cash Ratio terhadap Earning Per Share.

Diperoleh nilai $\mathrm{t}$ hitung sebesar $-2,706<\mathrm{t}$ tabel $(\mathrm{df}=\mathrm{n}-\mathrm{k}-1=12-2-1=$ 9) sebesar 1,833. Selain itu nilai probabilitas sebesar 0,024 lebih kecil dibandingkan dengan $a=5 \%=0,05$. Hal ini menunjukkan bahwa Cash Ratio terbukti berpengaruh negatif dan signifikan terhadap Earning Per Share. Ini berarti, semakin besar cash ratio suatu perusahaan maka semakin sedikit/kecil earning per share dan sebaliknya, apabila semakin kecil cash ratio disuatu perusahaan maka semakin besar earning per share. Dengan demikian, hipotesis pertama $\left(H_{1}\right)$ yang menyatakan bahwa cash ratio berpengaruh positif dan signifikan terhadap earning per share tidak diterima.

2) Uji Pengaruh individual (uji t) antara variabel ROE terhadap Earning Per Share.

Diperoleh nilai $\mathrm{t}$ hitung sebesar 10,605 $>\mathrm{t}$ tabel $(\mathrm{df}=\mathrm{n}-\mathrm{k}-1=12-2-1=$ 9) sebesar 1,833. Selain itu nilai probabilitas sebesar 0,000 lebih kecil dibandingkan $\alpha=5 \%=0,05$. Hal ini menunjukkan bahwa ROE terbukti berpengaruh positif dan signifikan terhadap Earning Per Share. Ini berarti, semakin besar ROE suatu perusahaan maka semakin besar pula earning per share dan sebaliknya, apabila semakin kecil ROE disuatu perusahaan maka semakin kecil pula earning per share. Dengan demikian, hipotesis pertama $\left(H_{1}\right)$ yang menyatakan bahwa $R O E$ berpengaruh positif dan signifikan terhadap earning per share diterima.

\section{Pembahasan}

a) Pengaruh Cash Ratio terhadap Earning Per Share

Diperoleh bahwa secara individual ada pengaruh negatif dan signifikan antara cash ratio terhadap earning per share. Hal ini dapat dilihat dari nilai thitung sebesar -2,706; koefisien regresi sebesar -468.820 dan nilai signifikansi 0,024. Pengaruh yang negatif dan signifikan ini mengindikasikan bahwa bahwa besar kecilnya arus kas yang diproksi dengan cash ratio berdampak pada nilai perusahaan yang diproksi oleh earning per share. Apabila semakin besar cash ratio, maka semakin sedikit/kecil earning per share dan sebaliknya. Dengan demikian, hipotesis 
PENGARUH ARUS KAS DAN PENGEMBALIAN MODAL TERHADAP NILAI PERUSAHAAN (STUDI PADA PT. HERO SUPERMARKET, TBK PERIODE 2004 - 2018)

Rida Ristiyana

kesatu $\left(H_{1}\right)$ yang menyatakan bahwa arus kas berpengaruh positif terhadap nilai perusahaan ditolak. Hasil penelitian ini konsisten dengan hasil penelitian Wartono (2018) dan penelitan ini tidak konsisten dengan hasil penelitian Nugroho (2017).

\section{b) Pengaruh ROE Terhadap Earning Per Share}

Diperoleh bahwa secara individual ada pengaruh positif dan signifikan antara ROE terhadap earning per share. Hal ini dapat dilihat dari nilai t hitung sebesar 10,605; koefisien regresi sebesar 3064,976 dan nilai signifikansi 0,000. Pengaruh yang positif dan signifikan ini mengindikasikan bahwa bahwa besar kecilnya pengembalian modal yang diproksi dengan $R O E$ berdampak pada nilai perusahaan yang diproksi oleh earning per share. Apabila semakin besar ROE perusahaan, maka semakin besar pula earning per share dan sebaliknya. Dengan demikian, hipotesis kesatu $\left(H_{2}\right)$ yang menyatakan bahwa pengembalian modal berpengaruh positif terhadap nilai perusahaan diterima.Hasil penelitian ini konsisten dengan hasil penelitian Yunina dkk (2009) dan penelitian ini tidak konsisten dengan hasil penelitian Diaz dan Jufrizen (2014) dan Yunina dkk (2009).

\section{E. PENUTUP \\ 1. Kesimpulan}

Berdasarkan pada hasil analisis yang telah dilakukan pada PT. Hero Supermarket, Tbk periode 2004-2018, dapat ditarik kesimpulan sebagai berikut:

a. Cash Ratio berpengaruh negatif dan signifikan terhadap Earning Per Share. Hal ini mengindikasikan bahwa, besar kecilnya arus kas yang diproksi dengan cash ratio berdampak pada nilai perusahaan yang diproksi oleh earning per share. Apabila semakin besar cash ratio, maka semakin sedikit/kecil EPSnya dan sebaliknya. Dengan demikian arus kas dapat memberikan kontribusi pada nilai perusahaan.

b. ROE berpengaruh positif dan signifikan terhadap Earning Per Share. Pengaruh yang positif dan signifikan ini mengindikasikan bahwa besar kecilnya pengembalian modal yang diproksi dengan $R O E$ berdampak pada nilai perusahaan yang diproksi oleh earning per share. Apabila semakin besar ROE perusahaan, maka semakin besar pula earning per share dan sebaliknya. Dengan demikian pengembalian modal dapat memberikan kontribusi pada nilai perusahaan.

c. Cash Ratio dan ROE berpengaruh secara bersama-sama terhadap Earning Per Share. 


\subsection{Implikasi}

Adapun impilikasinya, digolongkan menjadi :

\section{a) Implikasi Teoritis}

Secara teoritis, penelitian ini berimplikasi pada pengembangan arus kas dan nilai perusahaan. Hasil penelitian ini menunjukkan bahwa terdapatnya Cash Ratio dan ROE yang dapat memperbesar/memperkecil nilai perusahaan. Dengan demikian, hasil penelitian ini berimplikasi untuk menambah referensi kaitannya dengan hal-hal yang berpengaruh terhadap nilai perusahaan.

\section{b) Implikasi Praktik}

Implikasi praktek, dapat dikelompokkan menjadi :

1) Bagi Perusahaan

Memberikan informasi yang diharapkan akan menjadi baha pertimbangan dalam pengambilan keputusan dan kebijakan manajemen karena ada keterkaitan antara cash ratio dan ROE dengan earing per share.

2) Bagi Pemerintah

Penelitian ini juga dapat memberikan deskripsi kepada pemerintah untuk menilai nilai perusahaan PT. Hero Supermarket, Tbk melalui cash ratio dan $\mathrm{ROE}$.

\section{c) Implikasi Kebijakan}

Adapun implikasi kebijakan diantaranya :

Bagi Regulator, penelitian ini berimplikasi pada review terhadap efektivitas pemberlakuan peraturan yang telah dikeluarkan.

\section{Keterbatasan dan Saran}

\subsection{Keterbatasan}

Berikut keterbatasan yang ditemukan dalam penelitian ini, yaitu :

a. Pada penelitian ini hanya menggunakan satu perusahaan sebagai fokus studi yaitu PT. Hero Supermarket, Tbk.

b. Variabel yang digunakan hanya dua variabel independen yaitu arus kas dan pengembalian modal 
PENGARUH ARUS KAS DAN PENGEMBALIAN MODAL TERHADAP NILAI PERUSAHAAN (STUDI PADA PT. HERO SUPERMARKET, TBK PERIODE 2004 - 2018)

Rida Ristiyana

\subsection{Saran}

Adapun saran yang dapat diberikan sebagai berikut :

\section{a. Bagi Perusahaan}

PT. Hero Supermarket, Tbk dapat meningkatkan nilai perusahaan dengan mempertimbangkan cash ratio dan ROE karena keduanya memiliki kontribusi terhadap besar kecilnya nilai perusahaan yang ada.

\section{b. Bagi Investor dan Kreditur}

Investor dan kreditur dalam memprediksi nilai perusahaan PT. Hero Supermarket, Tbk perlu melihat cash ratio dan ROE dari hasil penelitian ini terbukti bahwa semakin besar cash ratio perusahaan akan menurunkan earning per sharenya, dan sebaliknya; semakin kecil jumlah cash ratio maka semakin banyak/besar nilai perusahaannya. Selain itu, semakin besar ROE, maka semakin besar/bertambah earning per sharenya dan sebaliknya. Dengan demikian investor dapat mengambil keputusan yang tepat dalam menginvestasikan dananya dengan mempertimbangkan nilai perusahaan dan kreditur juga dapat mempertimbangkan dalam hal pengambilan keputusan untuk memberikan pinjaman.

\section{c. Bagi Peneliti Selanjutnya}

Pada penelitian ini hanya menggunakan satu perusahaan sebagai fokus studi, diharapkan peneliti selanjutnya dapat menambah perusahaan-perusahaan retail lainnya supaya lebih generalisasi. Penelitian ini hanya menggunakan dua variabel independen diharapkan peneliti selanjutnya dapat menambahkan faktor-faktor lain yang sekiranya mempengaruhi nilai perusahaan. 


\section{Referensi}

Eliza. (2013)."Hubungan Nilai Intrinsik Suatu Saham terhadap Harga Pasar Tersebut", Jurnal Ekonomi Volume 4 Nomor 1.

Hanafiah, Ali, M. (2014). "Pengaruh Cureent Ratio, Quick Ratio, Inventory Turnover, Total Aset Turnover, Debt to Equity Ratio terhadap Earning Per Share pada Perusahaan Industri Barang Konsumsi yang terdaftar di Bursa Efek Indonesia Periode 2009-2012", E-Journal.

Hermuningsih, Sri. (2013). "Pengaruh profitabilitas, Growth Opportunity, Struktur Modal terhadap Nilai Perusahaan pada Perusahaan Publik di Indonesia", Buletin Ekonomi Moneter dan Perbankan, 129-147.

Junaidi, Nasir., dan Wiguna. (2014). "Pengaruh Return on Equity(roe), Cash Ratio(cr), Debt to Equity Ratio(der) dan Earning Per Share (eps) terhadap dividen Payout Ratio pada Perusahaan Jakarta Islamic Index yang Listing di Bei Periode 2008-2012", Jurnal JOMFEKON Vol 1 Nomor 2.

Kasmir, Dr. (2015). "Analisis Laporan Keuangan". Penerbit Rajawali Pers.

M.B. Uno, H. Tawas., dan P.V. Rate. (2014). "Analisis Kinerja Keuangan, Ukuran Perusahaan, Arus Kas Operasional Pengaruhnya terhadap Earning Per Share", Jurnal EMBA Volume 2 Nomor 3, 745-757.

Munawir. (2014). "Analisa Laporan Keuangan". Edisi Keempat. Penerbit Liberty: Yogyakarta.

Nugroho, Herbirowo., dkk. (2011). "Pengaruh Return on Equity dan Earning Per Share, Studi Kasus pada Kelompok Industri Farmasi yang terdaftar di Bursa Efek Indonesia", Jurnal Ekonomi dan Bisnis Vol 10 Nomor 1, 5258.

Rafika, Diaz., dan Jufrizen. (2014). "Pengaruh Return on Asset (ROA) dan Return on Equity (ROE) terhadap Earning Per Share (EPS) pada Perusahaan Asuransi yang terdaftar di Bursa Efek Indonesia", Jurnal Manajemen dan bisnis_Volume 12 Nomor 2, 1693-7619

Sugiyono, Prof. Dr. (2015). "Statistika untuk Penelitian". Penerbit Alfabeta Bandung.

Suharli., dan Oktorina. (2005). "Memprediksi Tingkat Pengembalian Investasi pada Equity Securities Melalui Rasio Profitabilitas, Likuiditas dan Hutang pada Perusahaan Publik dijakarta", Jurnal SNA VII,_288-296.

Trisnawati dan Wahidahwati. (2013). "Pengaruh Arus Kas Operasi, Investasi dan Pendanaan Serta Laba Bersih terhadap Return Saham", Jurnal Ilmu dan Riset Akutansi Volume 1 Nomor 1.

Untu, Frederik N. (2015). “Analisis Profitabilitas, Kebijakan Hutang, dan Price Earning Ratio terhadap Nilai Perusahaan Retail Trade yang terdaftar di Bursa Efek Indonesia". Jurnal EMBA Volume 3.Nomor 1 1242-1253. 
PENGARUH ARUS KAS DAN PENGEMBALIAN MODAL TERHADAP NILAI PERUSAHAAN (STUDI PADA PT. HERO SUPERMARKET, TBK PERIODE 2004 - 2018)

Rida Ristiyana

Pramita., dan Oetomo. (2013). "Pengaruh Cash Ratio, dan Growth of Company terhadap Dividen Payout Ratio", Jurnal Ilmu dan Riset Manajemen Volume 2 Nomor 4.

Pratama, Aditya., dkk. (2014). "Pengaruh Current Ratio, Debt to Equity Ratio, Return on Equity, Net Profit Margin dan Earning Per Share terhadap Harga Saham", Jurnal Akutansi Vol 2 Nomor 1.

Priatinah., dan Kusuma. (2012) "Pengaruh Return on investment (ROI), Earning Per Share (EPS), dan Dividen Per Share (DPS) terhadap Harga Saham Perusahaan Pertambangan yang terdaftar di Bursa Efek Indonesia (BEI) Periode 2008-2010", Jurnal Nominal Volume 1 Nomor 1, 50-61.

Puspitasari, Ratih. (2010). "Analisis Arus Kas Operasi dalam Mencapai Nilai Perusahaan yang Optimal Studi Kasus pada PT. Semen Gresik (Persero) Tbk.", Jurnal Ilmiah Kesatuan Volume 12 Nomor 2. 